\section{Clinical and Pharmacological Effects of Monoamine Precursors or Haloperidol in Chronic Schizophrenia}

MaNy psychotropic drugs have been shown to interfere with monoamine metabolism in the brain $^{1,2}$. Recently, interest has been focused on tryptophan and 5-hydroxy. tryptamine metabolism in mental depression ${ }^{3,4}$. During combined treatment with tryptophan and a monoamine oxidase inhibitor (MAOI) in healthy volunteers, mental effects described as drunkenness and hyperreflexia appeared ${ }^{5}$. In schizophrenic patients, the same combination of drugs caused central nervous stimulation and varying effects on the disease symptoms ${ }^{6-8}$ (reviewed in ref. 9). In contrast, 5-hydroxytryptophan also in combination with a monoamine oxidase inhibitor is reported to have no such effects on schizophrenic patients ${ }^{2,10}$. This discrepancy may depend on an accumulation of tryptamine after treatment with MAOI and tryptophan but not 5hydroxytryptophan. Because of these findings we have made therapeutic investigations of schizophrenic patients given single doses of monoamine precursors and at the same time made repeated estimations of acid monoamine metabolites in the lumbar cerebrospinal fluid. Asheroft et al. have pointed out that ventricular CSF rich in acid monoamine metabolites might reach the lumbar tap site if large amounts of cerebrospinal fluid were tapped ${ }^{11}$. In our study, however, the concentration of the acid monoamine metabolite which was uninfluenced by the treatments was unaffected by repeated tapping of the lumbar fluid. 5-Hydroxyindole acetic acid (5-HIAA) and homovanillic acid (HVA) in the cerebrospinal fluid were estimated by the methods of Roos ${ }^{12}$ and Andén, Roos and Werdinius ${ }^{13}$. Our patients had been in hospital for many years, and 14 days before these studies were undertaken all treatment was stopped.

One patient was given $50 \mathrm{mg}$ of DL-5-hydroxytryptophan intravenously. No mental effects could be observed and there seemed to be no discomfort. On the other hand there were considerable changes in the concentration of 5 hydroxyindole acetic acid in the cerebrospinal fluid (Table 1).

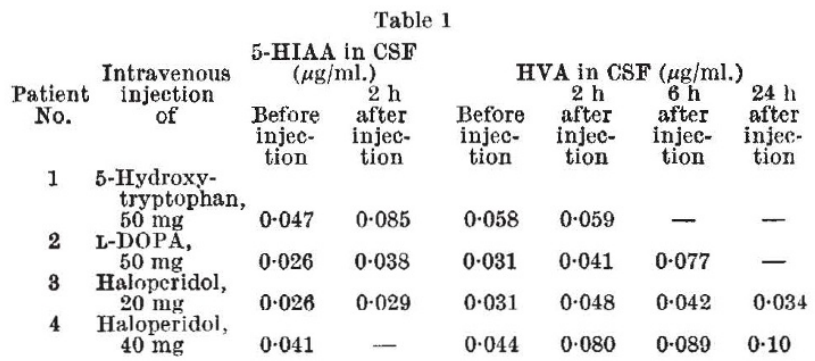

5-HIAA, 5-Hydroxyindole acetic acid; CSF, cerebrospinal fluid; HVA, homovanillic acid.

Another patient was given $50 \mathrm{mg}$ of $\mathrm{L}_{\text {-DOPA with no }}$ side effects nor apparent influence on the mental state. The concentration of homovanillic acid in the cerebrospinal fluid was, however, increased (Table 1). Bernheimer et al. ${ }^{14}$ gave $50 \mathrm{mg}$ of L-DOPA intravenously to both normal subjects and patients with various organic brain diseases but did not observe any changes of the concentration of homovanillic acid in the cerebrospinal fluid.

In two schizophrenic patients who, by mistake, happened to receive intravenous haloporidol, 20 and $40 \mathrm{mg}$, respectively, we could measure the concentrations of homovanillic acid and 5-hydroxyindole acetic acid in the cerebrospinal fluid at intervals up to $24 \mathrm{~h}$ after injection. Those patients had previously been treated with large doses of other neuroleptics but without effect. After the injections of haloperidol-they were free of other drugs - the patients were moderately sedated and showed mild orthostatic symptoms. Patient No. 4 (who received $40 \mathrm{mg}$ ) had a moderate hand and foot tremor for 4 days but showed no rigidity or motor unrest. There were no changes in the mental state despite mild sedation. The concentration of homovanillic acid in cerebrospinal fluid in this patient doubled within $6 \mathrm{~h}$ of tho injection. The patient who received $20 \mathrm{mg}$ of haloperidol showed no ehange in the concentration of homovanillic acid in the cerebrospinal fluid (Table 1). It has been shown experimentally that after doses of haloperidol or chlorpromazine comparable with those used in psychiatric therapy, homovanillic acid in the corpus striatum increases significantly ${ }^{15-17}$. It was therefore surprising that only after doses of $40 \mathrm{mg}$ was there a noticeable change in the concentration of homovanillic acid in the cerebro. spinal fluid. In dogs, however, a similar phenomenon has been encountered. A dose of $0.3 \mathrm{mg} / \mathrm{kg}$ of haloperidol in creased the homovanillic acid in the corpus striatum more than 100 per cent but had no influence on the homo. vanillic acid in the cerebrospinal fluid (unpublished re. sults of $\mathrm{H}$. Andersson).

This work was supported by the Swedish Medical Research Council and Läkemedelsindustriföreningen.

T. PERsSON

The Psychiatric Research Centre

St. Jörgen Hospital,

Lillhagen.

Department of Pharmacology,

University of Göteborg,

Göteborg, Sweden.

Received January 2, 1968.

I Schildkraut, J. J., Amer. J. Psychiat., 122, 509 (1965).

${ }^{2}$ Bunney. W. E., and Davis, J. M., Arch. Gen. Psychiat., 18, 483 (1965).

${ }^{3}$ Persson, T., and Roos, B.-E., Lancet, ii, 987 (1967).

'Coppen, A., Shaw, D. M., Herzberg, B., and Maggs, R., Lancet, Ii, 1178 (1967).

"Sjoerdsma, A., Oates, J. A., Zaltzman, P. O., and Udenfriend, S., J. Pharmacol. Exp. Ther.,126, 217 (1959).

" Lauer, J. W., Inskip, W. M., Bernsohn, J., and Zeller, E. A., Arch. Neurol. Psychiat., 80, 122 (1958).

'Pollin, W., Cardone, P., and Kety, S. S., Science, 133, 104 (1961).

${ }^{8}$ Alexander, T., Curtis, C. G., Sprince, H., and Crosley, A. P., J. Nerv, Ment. Dis, 137, 135 (1963).

- Psychopharmacology Bulletin, 4, 19 (1967).

${ }^{10}$ Feldstein, A., Freeman, H., Hope, J. M., Dibner, I. M., and Hoagland, H., A mer. J. Psychiat., I16. 219 (1959).

"Ashcroft, G. W., Crawford, T. B. B., Eceleston, D., Sharman, D. F. MacDougall, E. J., Stanton, J. B., and Binns, J. K., Lancet, ii, 1049 $(1966)$

${ }^{12}$ Roos, B.-E., Life Sci., 2, 1 (1963).

${ }^{13}$ Andén, N.-E., Roos. B.-E., and Werdinius, B., Life Sci., 2, 448 (1963).

14 Bernheimer, H., Birkmayer, W., and Hornykiewics, O., Wien. Klin. Wschr., 78, 417 (1966)

${ }^{16}$ Andén, N.-E., Roos, B.-E., and Werdiníus, B., Life Sci., 3, 149 (1904).

${ }^{16}$ Laverty, R., and Sharman, D. F., Brit. J, Pharmacol. Chemother., 24, 769 (1965).

"Juorio, A. V., Sharman, D. F., and Trajkov, T., Brit. J. Pharmneol. Chemother.,26, 385 (1966).

\section{MICROBIOLOGY}

\section{Isolation of Salmonella typhimurium Mutants with Increased Recipient Ability by the Use of $R$ Factor}

SEXUAL recombination occurs only at very low frequencies between Escherichia coli $\mathrm{Hfr}$ and Salmonella typhimurium rccipicnts ${ }^{1-5}$. Frequencies of transfer of $R$ factors ${ }^{8}$ from $E$. coli $R^{+}$to $S$. typhimurium $R^{-}$are also very low $\left(10^{-7}\right)$ donor $)^{7}$. Thus a characteristic feature of the mating of $E$. coli with $S$. typhimurium is the low recipient ability of Salmonella strains. The low recipient ability of Salmonella was overcome by isolating fertile mutants by an indirect selection method in S. typhimurium LT'7 mut ${ }^{5}$. We reported that these fertile mutants are rostrictionless and modificationless for foreign deoxyribonucleic acids (DNA) 